\title{
¿Hay choque de civilizaciones?
}

\section{Rafael López Pintor}

Universidad Autónoma de Madrid

Estas reflexiones en torno a los acontecimientos del 11 de septiembre, a solicitud de la REIS, tienen carácter coloquial y debo reconocer que me producen cierta incomodidad tanto por razones conceptuales como de los sentimientos. Conceptualmente, veo la inconveniencia de entrar en un texto de esta naturaleza a una disquisición sobre civilizaciones y sus conflictos; especialmente en la actuales circunstancias de shock por los acontecimientos de septiembre y el renovado interés del pronóstico de Samuel Huntington en el sentido de que el conflicto mundial del futuro estará determinado por un choque de civilizaciones más que por otras causas como las ambiciones territoriales o el capitalismo. Por otro lado, en el orden de los sentimientos y debido a mi propia experiencia en la mayor parte de los escenarios conflictivos de la postguerra fría, no hallo especial consolación en la "fabricación de pensamiento" acerca de una realidad que se nos muestra - ¿cómo podría ser de otra forma? - arrollada por la acción de gran velocidad. En todo caso, prometo ser breve y mostrarme apegado al mundo de los hechos lo más posible, tal y como yo los vivo y acierto a interpretar. Me permitiré plantear interrogantes más que avanzar respuestas acabadas que, desde luego, no tengo.

En primer lugar, ¿¿de qué estamos realmente hablando al hacernos eco de la alarma del viejo Huntington sobre un choque de civilizaciones? Creo que no merece la pena remontarse al clásico debate sobre cultura y civilización para sentir que se trata de un asunto serio. Dicho esto, conviene acotar enseguida la 
escena de los enfrentamientos al choque entre valores y formas de entender la vida (cualquiera que sean los intereses encubiertos) con capacidad para constituirse en ejes de conflicto político mundial. Hablamos de conflictos que involucran a las potencias (en la actual circunstancia, sólo una), pero que afectan directa o indirectamente a todo el mundo. Quedarían excluidas aquellas diferencias con un potencial conflictivo exclusivamente regional o local. Ejes arquetípicos del conflicto mundial en el siglo XX han sido nazismo/democracia y comunismo/capitalismo, coloreado este último por el más tenue eje norte/sur. Por otra parte, un conflicto regional en apariencia como el de israelíes y palestinos reviste, no obstante, características de eje mundial, aún más claramente después del 11 de septiembre. Conviene resaltar que, en la identificación de un nuevo eje mundial de conflicto definido por el enfrentamiento entre Islam y Occidente, no estaríamos —o al menos no todavía - ante un choque de civilizaciones, sino ante un ataque a la potencia norteamericana por parte de una organización terrorista ideológicamente sustentada en una versión radical de la religión musulmana. Sin negar que en buena medida los ataques de septiembre y su respuesta por parte de los Estados Unidos vienen espoleados por el conflicto palestino y tienen efectos de vuelta sobre el mismo (no olvidemos que la ruptura de las negociaciones entre Barak y Arafat y la subsiguiente victoria electoral de Sharon son anteriores al estado de violencia en Israel y los territorios palestinos, así como al 11 de septiembre de 2001).

En consecuencia, de lo que estamos tratando esencialmente es de la primera agresión histórica sobre el territorio continental estadounidense en una época en que los Estados Unidos se erigen en única potencia verdaderamente global, a gran distancia de las demás de segundo y tercer orden según capacidad militar, económica y diplomática. Por si fuera poco, los objetivos alcanzados por los agresores - Pentágono y Torres Gemelas - son relevantes en grado superlativo. ¿Cómo podrá extrañar el alcance de la respuesta? Sobre un adversario plural y evanescente, la respuesta aparece más orientada al medio y largo plazo que a la coyuntura; utiliza recursos militares tanto como policiales y de inteligencia; trata de modificar la política de alianzas y la geoestrategia. En suma, demanda y conduce a una redefinición del poder de la potencia agredida — quizá también de su autoridad, que podría evolucionar en sentido opuesto al de su poder-. Por doquiera que vayan nuestros afectos, una hipótesis alternativa a la del choque de las civilizaciones podría arrojar nueva luz sobre lo que está sucediendo. A saber, que los acontecimientos de septiembre y su respuesta, más que un conflicto entre valores civilizatorios, acaban fomentando nuevos enfrentamientos de intereses.

En segundo lugar, cabe preguntar si efectivamente los sistemas de valor y estilos de vida del mundo islámico son tan singulares como para acabar radicalmente contrapuestos a los del mundo occidental en su conjunto y/o a los del resto del mundo no islámico; hasta el punto de llegar a pensar en un choque de civilizaciones. Delimitar las fronteras reales de las civilizaciones vigentes en el mundo contemporáneo resultaría, sin duda, tarea ardua; y más aún deter- 
minar si algunas de ellas tienen fuerza contradictoria tal como para chocar, conformando así un eje mundial de conflicto. No niego que existan en nuestro mundo diferentes formas civilizatorias de extensión y vigencia variables; formas de vida sustancialmente ligadas a valores y códigos religiosos (ciertamente, la civilización occidental ligada al cristianismo; las civilizaciones asiáticas vinculadas al hinduismo, sintoísmo y budismo; y los países islámicos extendidos por tres continentes; sin olvidar la fuerza residual de las antiguas culturas del África subsahariana anteriores al Islam y al cristianismo). En este contexto cabe seguir preguntando: ¿sobre qué grado de homogeneidad social y política entre los diversos países afectados se asienta aquella civilización que más frecuentemente es considerada antagonista, es decir, la civilización islámica?

El mapa de los más de cincuenta países islámicos o con importantes minorías de religión musulmana es variopinto en términos geográficos, étnicos, de desarrollo económico y complejidad social: desde el Magreb y gran parte del África subsahariana, parte de Europa balcánica y meridional, Oriente Medio, Arabia y el Golfo Pérsico, Asia Central, Asia del Sur y Pacífico. Por un lado, solamente en África, los habitantes al norte de la franja sudanesa son casi todos musulmanes, con excepción de la minoría copta de Egipto. De igual manera, los países del Cuerno de África y de la costa este hasta el norte de Mozambique son islámicos, con excepción de la comunidad cristiana de la Iglesia etíope en la región central de Etiopía. Al sur de estas zonas casi totalmente islámicas hay un buen número de países de mayoría musulmana o con fuertes minorías musulmanas. Estamos, por tanto, ante un gran número de países de orígenes históricos y lenguas diferentes.

Hay en el mundo 48 países puramente islámicos, de los cuales 16 son países árabes, si incluimos Palestina. Hay 32 países no árabes pero de mayoría musulmana (si incluimos Kosovo); de los cuales 12 están en Europa (Albania,Turquía, Kosovo) y Asia Central, 6 en Asia del Sur y Pacífico, y 14 en África subsahariana. Todos tienen en común la religión musulmana, aunque en versiones y grados de práctica muy distintos. Resulta forzoso distinguir al menos entre países árabes y no árabes $\mathrm{y}$, dentro de cada categoría, distinguir grados de secularización cultural y política. En este sentido, y a modo de ejemplo, existe una distancia significativa entre Arabia Saudita, Yemen, Marruecos, Líbano y Palestina, dentro del mundo árabe. Por otro lado, y entre los países islámicos no árabes, la distancia políticocultural es enorme entre Turquía, Albania, Malasia y Sudán. Personalmente, he podido observar cómo en algunas sociedades islámicas (por ejemplo, Albania o Kosovo) apenas se escucha el canto del muecín; en otras, como Turquía o Palestina, no he visto que la llamada regular a la oración vaya acompañada por el rezo de numerosos creyentes - algo parecido a lo que sucede en nuestras secularizadas sociedades cristianas-; y sólo en las más tradicionales, como el Yemen, he visto rezar a muchos varones durante el día a la llamada a la oración, no importa el lugar en que se encuentren. También es importante resaltar los altibajos en el proceso de secularización tanto en el sector árabe como no árabe del mundo islámico. Existen ejemplos de radicalización religiosa extrema en el sector no árabe, como el 
Afganistán de los Talibán (si bien por poco tiempo), así como de un grado de secularización relativamente alto en un grupo de países del sector árabe (Siria, Líbano, Palestina, Marruecos).

Por otra parte, conviene recordar que, aun en los países más pobres, la fuerza civilizadora de las religiones en las sociedades del siglo XXI es declinante o de carácter secundario en comparación con la vigencia actual de la civilización urbano-industrial en los cinco continentes. El modo de vida urbanoindustrial tiende a imponerse, aunque sólo sea como aspiración popular y consumo de símbolos e imágenes a través de la radio y la televisión. Y, ciertamente, en sus manifestaciones más negativas de subempleo, chabolismo, criminalidad urbana y otras formas de marginación social.

Dadas las anteriores circunstancias, ¿qué posibilidades habría de que tal «mundo islámico» galvanizara a la manera de adversario bélico del mundo occidental? Desde Ibn Haldún hasta nuestros días, no han faltado los analistas poco sospechosos de anti-islamismo que han expresado serias dudas acerca de las posibilidades de unidad de las sociedades islámicas, más específicamente las del mundo árabe. No sólo la expansión del modo de vida urbano-industrial como padrón civilizatorio correría contra la posibilidad de un choque de civilizaciones. Otro factor a contracorriente de la hipótesis del choque sería la expansión universal del modelo democrático de gobierno (al menos como idea e iniciación institucional) y algunas de sus posibles consecuencias a la luz de la evidencia histórica. En casi todas las regiones del mundo, durante el último cuarto del siglo XX se han roto los sistemas autoritarios o totalitarios de gobierno dando paso, con intensidad y fidelidad variables, al modelo de democracia representativa. La tendencia general existe a juzgar por la experiencia electoral y los relativos avances del pluralismo político. El porcentaje de países en todo el mundo con gobiernos democráticamente elegidos ascendía en el 2001 a 63\% (121 de los 192 Estados existentes). Hace poco más de diez años dicho porcentaje era sólo un 40\% (66 de los 164 Estados existentes en 1988) (Journal of Democracy, vol. 13, núm. 1, enero 2002, p. 101).

La relevancia de este fenómeno de expansión universal de la democracia (bautizado como "tercera ola» de democratización por el propio autor de la hipótesis del choque de las civilizaciones, Samuel Huntington) radica en su conexión con una pieza de evidencia histórica raramente resaltada por los teóricos de la paz y el desarrollo: que nunca una democracia ha hecho la guerra a otra democracia. En la medida en que esta regla mantuviera su vigor mientras el fenómeno general de democratización continuara afirmándose (dos supuestos a no perder de vista), sería improbable que cristalizara una pauta de conflicto mundial basada precisamente en identidades civilizarorias tradicionales como las vinculadas a las tradiciones y culturas religiosas, en este caso islámica y occidental. Entiendo que éste es un punto de enorme relevancia analítica y estratégica. Bien es verdad que precisamente el grado de expansión del pluralismo democrático está siendo significativamente menor en el conjunto de países islámicos, más especialmente aún en el núcleo de países árabes. 
En efecto, solamente un $26 \%$ de los países islámicos tienen gobiernos elegidos en elecciones competitivas, mientras que entre los países no islámicos el $76 \%$ se consideran «democracias electorales». Debe destacarse que entre los 16 países árabes ninguno es una democracia electoral. Tomando el índice de Freedom House sobre el estado de los derechos y las libertades para el 2001 (clasifica a los países como «libres», "parcialmente libres» y «no libres»), entre los países islámicos sólo aparece uno en la categoría «libre» (Malí), frente a 18 "parcialmente libres» y 28 «no libres». Por el contrario, en el conjunto de países no islámicos, 85 se consideran «libres», 39 "parcialmente libres» y 21 «no libres». Dentro del mundo islámico, el porcentaje de países con menos libertad y sin elecciones competitivas es mayor en el conjunto de los países árabes y de Asia Central que en sur de Asia o el África subsahariana. No obstante, cabe destacar la presencia de países islámicos con una cultura política relativamente secularizada, algunos de ellos con larga tradición democrática electoral (Turquía, Líbano) o que acaban de abrirse a la democracia (Indonesia, Nigeria, Bangladesh, Albania, Kosovo). También existen países tradicionalmente democráticos, como la India, con una amplia población musulmana. (Un resumen del Informe de Freedom House, en Journal of Democracy, ibídem, pp. 99-112.)

Hasta aquí he mencionado cuatro factores que jugarían en contra de las probabilidades de un choque entre Islam y Occidente (el viejo orbe cristiano):

1. La complejidad interna del mundo islámico o conjunto de países con identidad religiosa exclusiva o predominantemente musulmana, en parte basada en el diferente grado de secularización cultural de estas sociedades, lo que conlleva la separación paulatina entre religión y política.

2. Una trayectoria histórica (Ibn Haldun dixit) de escasa armonía dentro del mundo islámico, especialmente de su sector árabe, donde las raíces religiosas son particularmente profundas.

3. La tendencia expansiva secular del modo de vida urbano industrial con sus efectos de secularización cultural. Adobado en las últimas décadas con la globalización de las comunicaciones.

4. La expansión del modelo democrático de gobierno, aunque menos rápida e intensa en el mundo islámico, con representación de múltiples partidos y protección de los derechos y libertades. La evidencia histórica enseña que las democracias no se hacen la guerra entre sí.

A modo de conclusión, me pregunto si con tanto hablar de «choque de civilizaciones» no estaremos fabricando una realidad a fuerza de pensarla para acabar moldeando el mundo como si tal choque hubiese tenido efectivamente lugar («lo que se percibe como real es real en sus consecuencias»). No deja de exhibir rasgos un tanto surrealistas y alarmantes el actual escenario de Afganistán, con la mayor potencia militar de la historia reprimiendo con armamento sofisticado a un enemigo escurridizo, hasta el día de ayer sostenido por viejos 
aliados de los Estados Unidos (Arabia Saudí, Pakistán), y el anuncio de futuras operaciones militares contra un eje del mal (Irak, Irán, Corea del Norte) sustentadas por coaliciones internacionales cambiantes. La legítima defensa del pueblo norteamericano contra grupos y organizaciones terroristas que amenazan su seguridad está más que justificada. Puede no estarlo tanto el identificar como una amenaza universal aquella que proviene de los adversarios ideológicos que en la coyuntura parecen resultar más incómodos.

Tiendo a pensar que, hoy por hoy, no existe una base objetiva como para predicar un "choque de civilizaciones» constituyendo o amenazando constituirse en eje de conflicto mundial. No obstante, en la profecía que se cumple a sí misma, podemos fabricar una tal base a fuerza de agitar nuestra imaginación y nuestras conciencias con fantasmas de cruzadas y guerras de religión del pasado - cualquiera que fuese su sustrato de intereses-. El riesgo de fuertes pérdidas en vidas humanas del lado "cristiano" sería (ya lo es) pequeño dada la superioridad militar de la potencia ofendida. La asimetría tecnológica con el adversario puede, paradójicamente, hacer el conflicto armado particularmente atractivo para los ejércitos profesionales y altamente burocratizados de las sociedades avanzadas. Se alejan los escenarios de guerra tradicionales con campos de batalla ensangrentados, prisioneros y heridos en masa. La "guerra de riesgo cero" golpearía (está golpeando ya) cada vez menos a una opinión pública de tiempos blandos: nada entusiasta del sacrificio personal y que sólo tolera la violencia hacia los otros contemplada a través de la televisión, instalada en el modelo informativo homo videns; fijada en la imagen y poco dada a la elucubración. Para una ciudadanía vivencialmente ajena a los ejércitos, el soldado es un profesional cuyo mayor riesgo laboral es la eventual pérdida de la vida con una frecuencia estadísticamente muy limitada, no muy diferente de algunas otras ocupaciones con mayor incidencia de riesgo mortal tales como pescadores, mineros y trabajadores de la construcción, que sin duda han sufrido mayores bajas en los últimos cuarenta años que muchos de los ejércitos de sus propios países.

No puedo dejar de apuntar algún remedio ante riesgos tan poco sensatos. Dado que el pensamiento condiciona la acción, generando nuevas realidades sobre las que otras acciones son requeridas a su vez (creamos el problema a fin de poder resolverlo, aunque en el camino surjan nuevos intereses más difíciles de justificar), permítaseme alguna propuesta alternativa a la de imaginar y actuar como si un choque de civilizaciones se estuviera produciendo. Por un lado, las verdaderas dimensiones del fenómeno terrorista deben ser identificadas en un esfuerzo honesto de investigación, colaboración y estrategia internacional. ¿Hasta dónde ciertos grupos se han convertido o participan en redes y en qué medida pueden asociarse y deslindarse de sociedades y Estados nacionales? Al menos en cuanto a metodología, supongo que algo puede compartirse con los trabajos sobre tráfico de armas, drogas y prostitución. Nunca antes el Estado nacional (aun la primera potencia) se vio tan desbordado por la extensión y el ritmo de la criminalidad internacionalmente organizada. El objetivo 
prioritario debe ser identificar grupos/redes y apoyos para poder contrarrestarlos/destruirlos. La lógica de este pensamiento difiere esencialmente de imaginar choques de dos mundos (occidental e islámico) que no admiten una delimitación nítida, presentan una gran diversidad interna y exhiben un pasado histórico de actuaciones menos que unitarias.

Por otro lado, a medio siglo de la segunda guerra mundial y unos lustros del fin de la guerra fría - fenómenos que dieron origen al hoy maltrecho sistema internacional-, convendría reexaminar el estado de la criatura en función de la salvaguarda de la esencial fraternidad humana. Evaluar la panoplia de soluciones propuestas en los años cincuenta y siguientes a los problemas que aquejan a la humanidad, en su vertiente política (evitar la guerra), económica (promover el desarrollo material), social (luchar contra la desigualdad) y cultural (tender puentes entre las diferentes formas de entender la vida). Imaginar y diseñar un futuro mejor evaluando el grado de validez actual de las antiguas respuestas y presentar otras alternativas al servicio de los mismos fines. Pero, entre otros obstáculos mayores, habrá que superar aquí la pereza del pensamiento - pensar cuesta trabajo, sobre todo en torno a lo más obvio- y la inercia de la acción, pues tendemos a actuar de la misma forma mientras no encontramos obstáculos insuperables. 